\title{
Turkish EFL teachers' attitudes towards online instruction throughout the Covid-19 outbreak
}

Mustafa Civelek $^{\mathrm{a} 1}$, Iş1lay Toplu ${ }^{\mathrm{b} 2}$, Levent Uzun *c 3

a,b Institute of Education Sciences, M.A. Program in ELT, Bursa Uludag University, Turkey

${ }^{c}$ English Language Teaching Department, Faculty of education Bursa Uludag University, Turkey

1'mustafacivelek179@gmail.com, ${ }^{2}$ isilaytoplu6@gmail.com, *33 ulevent@uludag.edu.tr

* corresponding author

\section{ARTICLE INFO}

\section{Article history}

Received 13 April 2021

Revised 29 June 2021

Accepted 21 August 2021

\section{Keywords}

online instruction

attitudes

EFL

obstacles

perceptions

\section{ABSTRACT}

The purpose of the present study is to shed light on the attitudes of Turkish EFL teachers towards online instruction (OI), the impact of training on their attitudes, the obstacles they encounter, and the strategies to deliver OI more successfully throughout the Covid-19 outbreak. The participants were 70 EFL teachers ( 52 female, 18 male). The data was collected through a questionnaire and semi-structured interviews. The data were analyzed by using SPSS 26 . Descriptive statistics of each item was calculated and an independent sample t-test was conducted to answer the research questions. For the analysis of the interview data, the responses of the participants were transcribed and the recurring themes were identified. The results revealed that the attitudes of Turkish EFL teachers, who experienced online instruction during the Covid-19 outbreak, are not as positive as expected regarding some of the results of the related research in the literature. The interview findings revealed that EFL teachers do not feel capable of delivering online instruction effectively since they do not have adequate knowledge and necessary skills to do that. In view of the findings, it's suggested that online instruction methodology should be integrated into teacher training programs and teachers should receive an in-service training about the related subject.

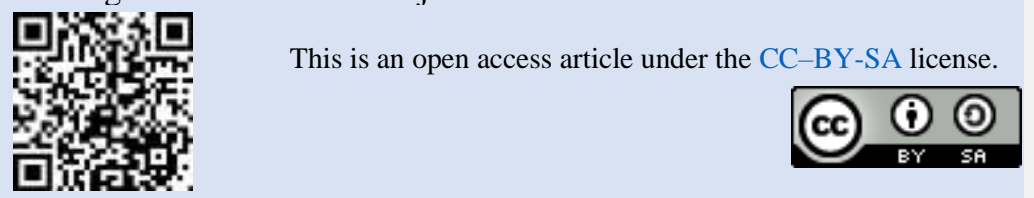

How to Cite: Civelek, M., Toplu, I., and Uzun, L. (2021). Turkish EFL teachers' attitudes towards online instruction throughout the Covid-19 outbreak. English Language Teaching Educational Journal, 4(2), 87-98

\section{Introduction}

In recent years, there has been growing recognition of the significance of Distance Education (DE) with the advancement in technology. Keegan (2002) defined DE as "teaching and learning in which learning normally occurs in a different place from teaching" (p. 20). Every teacher has more or less knowledge of implementing technology in her face-to-face classrooms. However, the Distance Educational Contexts (DEC) differ from the face-to-face environments in various ways such as interactional patterns, materials, methodologies, and techniques to be employed. DEC can be divided into two categories: synchronous distance educational context (SDEC) and asynchronous distance educational context (ASDEC). SDEC refers to the virtual educational environments in which learners and teachers come together and become active participants of interaction. Yet, learners and teachers are not required to be active participants in the learning and teaching process at the same time in ASDEC. Instead, learners communicate with their teacher through Asynchronous ComputerMediated Communication tools or are required to watch the recorded videos. 
The development in Information and Communication Technologies (ICT) has attracted great attention of scholars in the field of language teaching and this led to the nascence of sub-fields such as Computer-Assisted Language Learning (CALL) and Mobile-Assisted Language Learning (MALL). CALL and MALL technologies provide both teachers and learners with online instructional tools to support the learning process in DECs such as Computer-Mediated Communication tools, virtual meeting environments, software, websites, and instant messaging tools. Much research has been conducted to investigate the impact of Online Instruction (OI) on EFL learners' outcomes in various language areas (Eslami et al., 2015; Yen et al., 2015; Altay \& Altay, 2017). The findings of these studies revealed that $\mathrm{OI}$ is quite valuable for language teaching.

OI has been optional for language learners and teachers for a long time. However, it has become compulsory in almost all educational contexts after the Covid-19 outbreak. Like all the countries in the world, Turkey is also affected by the outburst of the pandemic. After the announcement of the first pandemic case in Turkey in March 2020, the Turkish National Ministry of Education declared the change from face-to-face instruction to DE at all levels from primary schools to graduate courses. In a short period, the Turkish National Ministry of Education established three TV channels for educational purposes not to hinder the learning process of students and asked teachers to conduct online sessions with their students in virtual meeting environments such as Zoom, Skype, Google Meet, Team Link, and Microsoft Teams.

This sudden shift from traditional classrooms to virtual learning environments helps learners maintain their language learning process. In addition to this, it has been noted that OI has supplied language learners with a variety of potentialities such as cooperating with their peers, enhancing their critical thinking skills, providing opportunities for innovative tasks, and increasing awareness about life-long learning in digital platforms (Hazaymeh, 2021). Moreover, teachers unintentionally replace traditional materials they use with more innovative multisensory materials. Such materials are reported to contribute to learners' language skills by motivating them, and making learning more concrete and fun (Çelik-Kormaz \& Karatepe, 2018; 2021). Along with all these potentialities, this shift has brought about notable challenges for both language learners and teachers (Hakim, 2020; Khatoony \& Nezhadmehr, 2020; Mathew et al., 2019; Nenakhova, 2021). It would not be an exaggeration to claim that such obstacles may put too much stress on teachers, which is likely to impact their instructional practices and views regarding OI in a negative way.

Even though several studies had investigated the attitudes of EFL teachers towards OI (Osika, Johnson \& Butea, 2009; Dashtestani, 2014), they were mostly carried out with teachers who had little or no OI experience. The studies regarding the views of EFL teachers about OI throughout the Covid19 pandemic are scarce (Housseine \& Rabha, 2020; Nugroho \& Mutiaraningrum, 2020). Due to the increasing significance of OI over the last two years, it has become compulsory for researchers to question EFL teachers' views and experiences in terms of OI. Yet, such studies, to the authors' knowledge, have not been conducted in Turkish educational context. The studies conducted in the other parts of the world during the outbreak recommended covering methodologies and techniques regarding the implementation of $\mathrm{OI}$ in teacher training programs to cope with the anticipated challenges (Khatoony \& Nezhadmehr, 2020; Nugroho et al., 2021). Thus, this paper intends to contribute to the growing body of literature by investigating how the Turkish EFL teachers with training on OI differ from the ones having no training in terms of their attitudes to this end. Additionally, the present paper aims at shedding light on the obstacles the participants encounter during the Covid-19 outbreak and their opinions about the strategies to deliver more successful OI.

The CALL technologies enable language teachers to employ various tools to enhance the language learning process of their learners. Yet, it is a challenging task for language teachers to use such tools in their teaching practices for the reason that they do not have adequate skills and knowledge to this end. In Turkish EFL teacher training programmes, there is a course named "Education Technologies" which focuses on the integration of technology for language instruction (www.yok.gov.tr). Uzun (2016) argued that other courses offered in teacher training programmes in Turkey fail to foster prospective teachers' skills regarding technology use for instructional purposes. Seeing this, is one course enough to equip prospective teachers with the necessary knowledge and skills to employ CALL technologies effectively for both face-to-face classrooms and DECs?

Rizvi, Rienties, and Khoja (2019) emphasized that the number of people willing to become online learners is increasing. However, OI has been considered as a supplementary practice in respect to the 
blended-classroom approach in English language teaching for a long time. Surprisingly, it has become an inevitable part of every language teachers' life because of the Covid-19 outbreak. In such situations, OI can be useful to maintain language teaching and learning regardless of space and time. Sun (2014) emphasized that it is uncommon to find research shedding light on fully online learning. Yet, fully OI has drastically attracted great attention of researchers in the field with the outburst of the Covid-19 pandemic. A significant number of studies about OI have brought attention to the opinions of EFL teachers since it has been noted that teachers' beliefs play a vital role in their instructional practices (Carter \& Doyle, 1995).

Long before the pandemic, Osika, Johnson, and Butea (2009) carried out a case study at Chicago University to investigate the factors affecting faculty instructors' decisions of whether or not to implement OI. They reported that perceptions of OI, the instructors' past experiences regarding online technologies, and particular experiences at the university were core factors influencing instructors' choice in terms of OI. The findings indicated that nearly half of the instructors believed that OI was not as effective as traditional classes. The reasons behind these instructors' negative beliefs about online classes were the learners' inability to use online tools and technological problems. On the other hand, flexibility and success with previously used technologies were among the factors that motivated the teachers to deliver OI. Similarly, Belanger and Jordan (2000) also advocated that distance learning increases flexibility.

In another research, Dashtestani (2014) unravelled the attitudes of EFL teachers towards OI, the possible obstacles of OI, and EFL teachers' perceptions about the strategies to include more OI in Iran. In view of the analysis of both quantitative and qualitative data, it was reported that although EFL teachers mostly held positive attitudes towards OI, they preferred blended instruction over fully OI. They also expressed some challenges that language teachers might encounter while delivering OI such as lack of online resources and facilities, learners' negative attitudes towards OI, and EFL teachers' inadequate knowledge in terms of OI. They also suggested that authorities should take all necessary steps to improve the quality of OI since it was an inevitable component of the educational contexts of the near future. In addition, Atmojo and Nugroho (2020) underscored the significance of teacher training for technology integration to deliver effective OI. Since teachers are mostly the main source of information in educational contexts where English is taught and learned as a foreign language, their beliefs, attitudes, and knowledge play a vital role in the way they implement OI.

Learners' attitudes towards OI have also been a topic of interest in the field. For example, Erarslan and Zehir-Topkaya (2017) examined both the opinions of EFL learners about OI and their outcomes through an online English course. Their findings indicated that the learners adopted partly positive attitudes towards OI. Some of them positioned OI as an optional-extra in their language learning process. Additionally, the learners' exam results documented that their online exam results were relatively low when compared to face-to-face classes. Considering the findings of this research, it can be concluded that the attitudes of learners are as important as teachers' attitudes to achieve successful outcomes in OI.

More recent research regarding OI has drawn attention to EFL teachers' and learners' views, their practices, and the challenges they encounter throughout the Covid-19 outbreak in this regard. For illustration, Housseine and Rabha (2020) conducted a study to investigate the attitudes of EFL teachers towards DE and the challenges they experience during the covid-19 outbreak in Morocco. It was seen in the research that $98 \%$ of the teachers delivered online sessions by employing various instant messaging or virtual meeting tools such as Whatsapp, Facebook, Google classroom, and Zoom, etc. The results indicated that most of the participants held positive attitudes towards OI; however, they also reported a variety of challenges they experienced during their online sessions such as technical issues, managerial issues, lack of student interest and interaction, and unsatisfactory knowledge of teachers. In the light of the findings, it can be concluded that there is still a lot to be improved for more effective OI to take place.

Similarly, Nugroho and Mutiaraningrum (2020) conducted a case study to explore non-native EFL instructors' beliefs about digital learning and their instructional practices during covid-19 pandemic at a public university in Indonesia. The participants were selected based on 2 criteria: (1) having at least three years of experience, and (2) integrating digital tools in their teaching practices. Their findings revealed that the instructors were aware of the significance of digital learning. Yet, they reported some personal and contextual challenges which prevented them from carrying out their 
beliefs. Some of these challenges were poor internet connection, lack of time and resources to prepare the most efficient materials for distance learning, teachers' lack of training regarding OI and teaching efficacy. The researchers suggested that the professional development of teachers is required to be enhanced through training on technology integration to increase the quality of OI.

Additionally, Khatoony and Nezhadmehr (2020) aimed to find out the effectiveness of OI and the challenges that graduate and undergraduate Iranian EFL teachers came across during Covid-19 pandemic. The study revealed that although the teachers adopted positive views on the integration of technology, they had some challenges such as the lack of suitable materials, students' demotivation, and inadequate support for language institutions. It was also pointed out that various technologies could be rewarding to miniaturize the distance between instructors and learners in such situations like pandemics.

Likewise, Atmojo and Nugroho (2020) investigated the challenges of OI during the Covid-19 outbreak in their study. They reported that the problems were related to the teachers, students, and parents. One of the reasons was financial factor. The parents could not afford a smartphone or they did not have an internet connection in their homes. Moreover, the learners were not equipped with the necessary knowledge and skills to use digital devices and they could not comprehend the instructions. Not only students but also teachers had difficulty in implementing online classes because of inadequate experience and preparation. Another challenge mentioned in the study is the inadequacy of time allocated to the teachers. It was concluded in the study that OI is not regarded as successful due to the lack of preparation and planning. In another study (Lassoued et al.,2020), the challenges for succeeding in quality in OI are categorized as personal, pedagogical, technical, and financial.

Apart from the research mentioned previously in this section, the studies regarding OI during the pandemic also focused on the views of EFL learners, their learning experiences, and obstacles they come across (For example; Allo, 2020; Almusharraf \& Khahro, 2020; Octoberlina \& Muslimin, 2020; Pasaribu \& Dewi, 2021). Pasaribu and Dewi (2021) highlighted the significance of OI to improve learners' engagement and autonomy. Allo (2020) demonstrated that EFL learners perceive OI helpful during the Covid-19 outbreak. Yet, it has been noted that they encountered some obstacles throughout their online learning experiences such as lack of experience regarding e-learning, physical issues, and heavy internet connection (Octaberlina \& Muslimin, 2020).

This paper aims to investigate the attitudes of EFL teachers towards OI, the obstacles they encounter during their instructional practices, and the strategies to include OI more effectively. As different from the studies conducted before, this paper examines the impact of training on teachers' attitudes regarding OI since many researchers recommended teacher training as a solution to cope with the issues in this respect (Dashtestani, 2014; Aliyyah et al., 2020; Atmojo \& Nugroho,2020; Khatoony \& Nezhadmehr, 2020; Nugroho \& Mutiaraningrum, 2020).

The present study aims to reveal the answers to the following questions;

(1) What are the attitudes of Turkish EFL teachers, who had the experience of DE throughout the Covid-19 outbreak, towards OI?

(2) Is there a significant difference between the attitudes of Turkish EFL teachers who had learned about implementing OI during their academic studies and the ones who hadn't?

(3) What are the opinions of Turkish EFL teachers, who had the experience of DE throughout the Covid-19 outbreak, on the obstacles of OI?

(4) What are the perceptions of Turkish EFL teachers, who had the experience of DE throughout the Covid-19 outbreak, on the strategies that should be employed for the integration of OI in Turkey?

\section{Method}

This study was based on a mixed-method design that was defined as "the collection, analysis, and integration of quantitative and qualitative data in a single or multiphase study" (Hanson et al., 2005, p. 224). 


\subsection{Participants}

The participants of this study were 70 Turkish EFL teachers (52 female, 18 male) teaching different age groups (see Table 1). The participants' teaching experience varied from 1 to 26 years which meant the study involved both novice and experienced EFL teachers. Their ages ranged from 22 to 50. All of the participants received formal education at BA level (at least) to teach English. However, $57.1 \%$ of the participants have not received education on the use of educational technologies for OI during their academic studies.

Table 1. Demographic Information about Participants

\begin{tabular}{|c|c|c|}
\hline Workplace & Female & Male \\
\hline Primary school & 11 & 3 \\
\hline Middle school & 14 & 6 \\
\hline High school & 19 & 6 \\
\hline University & 6 & 2 \\
\hline Freelance & 2 & 1 \\
\hline Total & 52 & 18 \\
\hline
\end{tabular}

\subsection{Instruments and Data Collection Procedure}

\subsubsection{Questionnaire}

The questionnaire developed by Dashtestani (2014) was adapted and employed for data collection. Dashtestani's study was conducted with EFL teachers with little or no OI experience, thus employing this questionnaire enabled the researchers to compare the results of EFL teachers who had little or no OI experience and the ones who had. Few changes were made to the questionnaire statements to make it more useful to investigate the perspectives of Turkish EFL teachers who had the experience of OI throughout the Covid-19 outbreak. The changes included the wording of the questionnaire, and the deletion of two items to make the data collection tool served the purpose of the study. The final version of the questionnaire consisted of 32 items. The questionnaire included three subscales: (1) attitudes of EFL teachers towards OI, (2) obstacles of OI, and (3) strategies to include OI in EFL teaching. The modified version of the questionnaire was given to two experts in order to establish content validity. Furthermore, it was piloted with 15 EFL teachers who were not the actual participants of the current study so as to evaluate the clarity of the items. The first sub-scale provided the researchers with the answers of research questions 1 and 2; the second one to research question 3; and the third one to research question 4 .

The questionnaire was presented in Google forms format and the URL was shared with the participants via WhatsApp and they were kindly asked to fill out the questionnaire and share it with their colleagues. Snowball sampling was employed as the sampling strategy. Snowball sampling is efficient at times when it is difficult to access participants (Cohen et al., 2007). The data was collected during the Covid-19 outbreak so it was difficult to employ other data collection strategies.

\subsubsection{Interview Protocol}

After the analysis of the questionnaire data, 10 participants who mostly demonstrated negative attitudes towards OI were invited to take part in the interview protocol. Since EFL teachers showed highly positive opinions about OI in the previous study (Dashtestani, 2014), "a semi-structured interview" (Cohen et al., 2007, p.361) was employed to explore the reasons behind the participants' negative attitudes towards OI. The following open-ended questions were addressed to the interviewees in Turkish;

(1) Why do you think OI is not as effective as face-to-face instruction in EFL courses?

(2) What are the challenges of OI you experience in your lessons? 
(3) Do you think you have adequate skills to implement OI?

(4) What can be done to include OI more effectively in EFL courses in Turkey?

\subsection{Data Analysis}

The questionnaire data were analysed by using SPSS 26. The Cronbach's Alpha values of each sub-scale were calculated and they were found to be reliable. The Cronbach's Alpha values of each scale is presented in Table 2.

Table 2. Sub-scales and their Cronbach's Alpha Scores

\begin{tabular}{lcc}
\hline \multicolumn{1}{c}{ Scale } & Number of Items & Cronbach's Alpha Score \\
\hline Attitudes of EFL teachers towards OI & 16 & 0.88 \\
Obstacles of OI in EFL & 11 & 0.84 \\
Strategies to include OI in EFL & 5 & 0.71 \\
\hline
\end{tabular}

In order to answer research questions 1,3 , and 4, descriptive statistics were calculated and presented in tables. To find out whether there is a significant difference between the teachers who had been taught about educational technologies to be employed for OI and the ones who hadn't, an independent sample t-test, which is a parametric test, was conducted since the normality test results revealed that skewness and kurtosis values were between +1.5 and -1.5 which means the data was normally distributed (Tabachnick \& Fidell, 2013).

For the analysis of the interview data, content analysis was employed. The responses of the participants were transcribed and recurring themes were identified. The findings were presented in a table in which each interviewee was given a number rather than their names for anonymity considerations.

\section{Findings and Discussion}

\subsection{Findings}

Research Question 1 was constructed to investigate the attitudes of Turkish EFL teachers, who experienced OI during the Covid-19 outbreak, towards OI. To this end, the descriptive statistics of the participants' responses to the questionnaire items were presented in Table 3.

The results presented in Table 3 revealed that Turkish EFL teachers, who experienced OI throughout the Covid-19 outbreak, showed positive attitudes towards OI in terms of the use of multimedia, availability of various materials, its impact on learners' and teachers' computer competence, and cost-effectiveness. However, they maintained undecided or demonstrated negative attitudes towards other aspects of OI. While the use of multimedia in OI received the highest score in the questionnaire $(\mathrm{M}=4.55)$, the participants significantly disagreed that OI provides equal opportunities for all learners $(M=2.30)$. To get in-depth information about the reasons why EFL teachers had negative attitudes towards OI, 4 open-ended questions were asked to 10 participants. The interview findings supported the questionnaire results as seen in Table 4.

Research Question 2 aimed at revealing whether there is a significant difference between the attitudes of Turkish EFL teachers, who had been taught about educational technologies to be employed in OI and the ones who hadn't. To this end, an independent sample t-test was conducted. The t-test results demonstrated a significant difference $(p=.002<0.05$, Cohen's $d=0.44)$. Furthermore, the $t-$ test result indicated that the participants who had been taught about the educational technologies $(\mathrm{M}=$ 3.51) hold more positive attitudes towards OI than the ones who hadn't $(\mathrm{M}=3.01)$ as seen in Table 5.

To answer Research Question 3 regarding the obstacles that teachers experienced during OI throughout the Covid-19 pandemic, the descriptive statistics data of the questionnaire items regarding the obstacles of OI are presented in Table 6 . The findings demonstrated in Table 6 revealed that each questionnaire statement, which was presented in the subscale regarding obstacles of OI, was recognised as an obstacle more or less by Turkish EFL teachers. 
Table 3. Turkish EFL Teachers' Attitudes towards OI

\begin{tabular}{|c|c|c|c|c|c|}
\hline \multirow[t]{2}{*}{ Scale } & \multicolumn{3}{|c|}{ Percent (\%) } & \multirow[t]{2}{*}{ Mean } & \multirow[t]{2}{*}{ SD } \\
\hline & Disagree & Undecided & Agree & & \\
\hline Students become more autonomous in online EFL courses & 27.1 & 35.7 & 37.2 & 3.14 & 1.20 \\
\hline Online EFL courses enhance students' motivation & 55.7 & 25.7 & 18.6 & 2.51 & 1.17 \\
\hline Online EFL courses are time-efficient & 28.6 & 25.7 & 45.7 & 3.35 & 1.09 \\
\hline Authentic materials are used in online EFL courses & 20.0 & 35.7 & 44.3 & 3.38 & 1.17 \\
\hline Learners can communicate internationally in online EFL courses & 24.3 & 31.4 & 44.3 & 3.31 & 1.24 \\
\hline $\begin{array}{l}\text { Online EFL courses are based on learner-centred approaches to } \\
\text { teaching }\end{array}$ & 38.6 & 30.0 & 31.4 & 2.92 & 1.14 \\
\hline Online EFL courses are easily accessible to students & 42.8 & 12.9 & 44.3 & 2.97 & 1.34 \\
\hline Multimedia can be used in online EFL courses & 1.4 & 7.1 & 91.5 & 4.55 & 0.69 \\
\hline Various types of materials can be used in online EFL courses & 8.6 & 17.1 & 74.3 & 4.08 & 0.97 \\
\hline Online EFL courses are cost-effective & 12.8 & 24.3 & 62.9 & 3.72 & 1.12 \\
\hline $\begin{array}{l}\text { Online EFL courses promote students' and teachers' computer } \\
\text { competence }\end{array}$ & 4.3 & 12.9 & 87.2 & 4.25 & 0.89 \\
\hline $\begin{array}{l}\text { Online EFL courses provide equal opportunities for learners to } \\
\text { learn English }\end{array}$ & 61.4 & 18.6 & 20.0 & 2.30 & 1.27 \\
\hline Online EFL courses promote collaboration among students & 55.7 & 28.6 & 15.7 & 2.44 & 1.07 \\
\hline $\begin{array}{l}\text { Expansive feedback can be provided for students in online EFL } \\
\text { courses }\end{array}$ & 24.3 & 28.6 & 37.1 & 3.08 & 1.11 \\
\hline Online EFL courses are easy to be implemented & 30.0 & 28.6 & 41.4 & 3.17 & 1.14 \\
\hline Online EFL courses are more interactive than traditional courses & 58.6 & 18.6 & 22.8 & 2.45 & 1.33 \\
\hline
\end{tabular}

Table 4. Reasons of Participants for Their Negative Attitudes towards OI

\begin{tabular}{ll}
\hline \multicolumn{1}{c}{ Reason for Negative Attitudes towards OI } & \multicolumn{1}{c}{ Participants } \\
\hline $\begin{array}{l}\text { I don't have adequate knowledge and skills about educational technologies } \\
\text { Students are not eager to participate in online sessions }\end{array}$ & P1, P2, P3, P4, P5, P7 \\
It's difficult to check whether students understand the lesson content & P1, P2, P4, P7, P9 \\
$\begin{array}{l}\text { I can't make sure whether all the students listen to me } \\
\text { It is difficult to attract learners' attention in online sessions }\end{array}$ & P2, P4, P8, P9 \\
$\begin{array}{l}\text { It is difficult to teach lower-level learners online. } \\
\text { It is mostly "teacher to whole class" interaction in OI }\end{array}$ & P2, P3, P4, P10 \\
$\begin{array}{l}\text { Each student doesn't have access to the necessary equipment to participate in } \\
\text { online sessions }\end{array}$ & P1, P2, P3, P9 \\
$\begin{array}{l}\text { Virtual meeting applications I use for OI lack some features of face-to-face } \\
\text { classrooms }\end{array}$ & P3, P5, P8, P9, P10 \\
Students do not have the necessary skills for OI. & P2, P6 \\
\hline
\end{tabular}


Table 5. Independent Samples t-test Results

\begin{tabular}{cccccc}
\hline Groups & N & $\overline{\mathbf{x}}$ & SD & t & p \\
\hline $1^{\text {st }}$ Group & 30 & 3,51 & 0.77 & 3.15 & .002 \\
$2^{\text {nd }}$ Group & 40 & 3,01 & 0.54 & & \\
\hline
\end{tabular}

Table 6. Obstacles of OI

\begin{tabular}{|c|c|c|c|c|c|}
\hline \multirow[t]{2}{*}{ Scale } & \multicolumn{3}{|c|}{ Percent (\%) } & \multirow[t]{2}{*}{ Mean } & \multirow[t]{2}{*}{ SD } \\
\hline & Disagree & Undecided & Agree & & \\
\hline There is a lack of online facilities in EFL courses & 28.5 & 27.1 & 44.2 & 3.21 & 1.24 \\
\hline $\begin{array}{l}\text { Students lack the necessary Internet-based skills to } \\
\text { participate in online ELT courses }\end{array}$ & 27.1 & 37.1 & 35.7 & 3.24 & 1.18 \\
\hline $\begin{array}{l}\text { There are cultural resistances to the implementation } \\
\text { of online EFL teaching }\end{array}$ & 30.0 & 24.3 & 45.7 & 3.25 & 1.20 \\
\hline There is a lack of interaction in online EFL courses & 22.9 & 18.6 & 58.6 & 3.55 & 1.28 \\
\hline $\begin{array}{l}\text { Students do not have positive attitudes towards } \\
\text { online EFL courses }\end{array}$ & 28.5 & 18.6 & 52.9 & 3.47 & 1.17 \\
\hline $\begin{array}{l}\text { Online EFL courses are just appropriate for } \\
\text { autonomous students }\end{array}$ & 25.7 & 21.4 & 52.9 & 3.47 & 1.20 \\
\hline $\begin{array}{l}\text { There is not much teacher supervision over students } \\
\text { in online EFL courses }\end{array}$ & 30.3 & 25.7 & 50.0 & 3.37 & 1.28 \\
\hline $\begin{array}{l}\text { Online EFL courses are not responsive to students' } \\
\text { needs }\end{array}$ & 31.5 & 31.4 & 37.1 & 3.17 & 1.12 \\
\hline $\begin{array}{l}\text { Online EFL teaching is costly to be implemented in } \\
\text { TEFL contexts }\end{array}$ & 27.2 & 44.3 & 28.6 & 3.04 & 0.90 \\
\hline $\begin{array}{l}\text { Online EFL courses place a lot of demands on EFL } \\
\text { teachers }\end{array}$ & 12.9 & 27.1 & 60.0 & 3.70 & 1.05 \\
\hline Online EFL courses are not motivating for students & 25.7 & 24.3 & 50.0 & 3.41 & 1.24 \\
\hline
\end{tabular}

Regarding Research Question 4 asking the perspectives of EFL teachers about strategies to integrate OI, the descriptive statistics of the related subscale were calculated and presented in Table 7. As the numbers in Table 7 indicate, EFL teachers had positive perceptions about the OI integration strategies such as improving online facilities in EFL courses, providing both students and teachers with training on the use of educational technologies, combining face-to-face EFL courses with online ones, training EFL teachers on online EFL teaching methodologies. However, they strongly rejected the idea of replacing face-to-face EFL courses with online ones.

Table 7. Strategies to Integrate OI in EFL Courses

\begin{tabular}{|c|c|c|c|c|c|}
\hline \multirow[t]{2}{*}{ Scale } & \multicolumn{3}{|c|}{ Percent (\%) } & \multirow[t]{2}{*}{ Mean } & \multirow[t]{2}{*}{ SD } \\
\hline & Disagree & Undecided & Agree & & \\
\hline $\begin{array}{l}\text { Computer-based and online facilities should be improved in } \\
\text { EFL courses }\end{array}$ & 4.3 & 5.7 & 90.0 & 4.45 & 0.84 \\
\hline $\begin{array}{l}\text { Students and teachers should receive training on online } \\
\text { computer literacy skills }\end{array}$ & 5.7 & 4.3 & 90.0 & 4.48 & 0.88 \\
\hline $\begin{array}{l}\text { Online EFL courses should be combined with face-to-face } \\
\text { EFL courses }\end{array}$ & 8.6 & 15.7 & 75.7 & 4.11 & 1.13 \\
\hline $\begin{array}{l}\text { EFL teachers should receive training on online EFL teaching } \\
\text { methodologies }\end{array}$ & 5.8 & 7.1 & 87.1 & 4.48 & 0.95 \\
\hline $\begin{array}{l}\text { Online EFL courses should replace the traditional EFL } \\
\text { courses }\end{array}$ & 64.3 & 22.9 & 12.8 & 2.15 & 1.22 \\
\hline
\end{tabular}




\subsection{Discussion}

This paper is an attempt to investigate the attitudes of Turkish EFL teachers towards OI, the challenges they encounter, and their perceptions about the strategies to implement OI in EFL courses during the Covid-19 outbreak. Firstly, the study aimed to explore the attitudes of Turkish EFL teachers towards OI. The interview and questionnaire indicated that even though Turkish EFL teachers have positive attitudes towards OI, they are not found to be as positive as the ones demonstrated in the study of Dashtestani (2014). However, the findings of this study are in line with some other studies (Aliyyah et al., 2020; Atmojo \& Nugroho, 2020; Nugroho \& Mutiaraningrum, 2020). That is, the studies conducted with the inexperienced teachers regarding OI revealed more positive attitudes than the ones conducted with EFL teachers with OI experience during the Covid-19 outbreak. Therefore, the reason behind the differences among the findings of the related studies may be the period in which they were conducted. The quantitative results also revealed that EFL teachers disagree that OI provides equal opportunities for each student.

Secondly, the study questioned whether there is a statistically significant difference between the attitudes of EFL teachers who were trained about OI and the ones who weren't. The results revealed that training had a positive impact on the participants' attitudes towards OI. The significance of teacher training on effective OI has been argued in the previous research, and it was recommended for teacher training programs to revisit their curriculums to equip teacher candidates with necessary knowledge and skills for more effective OI (Dashtestani, 2014; Atmojo \&Nugroho, 2020; Lassoued et al.,2020; Nugroho \& Mutiaraningrum, 2020). The findings of this study supported these recommendations with an analytic ground. The qualitative findings provided rich information about the reasons behind EFL teachers' negative attitudes towards OI. Teachers' inadequate knowledge and skills, lack of facilities in virtual meeting programs, demotivation, and lack of interaction and collaboration among students are the most frequently expressed reasons by the participants and these challenges were reported in the previous research (Atmojo \& Nugroho, 2020; Khatoony\& Nezhadmehr, 2020; Aliyyah et al., 2020; Housseine \& Rabha, 2020).

Considering the third research question, the obstacles of OI have been investigated. The quantitative results were in support of the above mentioned qualitative ones. Sepulveda-Escobar and Morrison (2020) also emphasized the lack of interaction in OI. As opposed to these studies, Khatoony and Nezhadmehr (2020) reported that OI increases the interaction between students and their teacher. However, the demotivation of the students is stated as a negative side of OI in some studies (Khatoony and Nezhadmehr, 2020; Housseine \& Rabha, 2020). The fourth research question asked teachers' perceptions of strategies to include OI more effectively in EFL courses. The results revealed that they strongly disagree with the replacement of face to face classes with OI. Similarly, it was seen in Osika, Johnson, and Butea's (2009) study that most of the teachers believe that online courses are not equivalent to traditional classrooms. However, EFL teachers in the study strongly support the incorporation of the training regarding OI into teacher training programs to implement OI more effectively.

\section{Conclusion}

With the outburst of the Covid-19 pandemic, teachers are required to replace their face-to-face lessons with online lessons unpredictably. In the literature review, it is emphasized that the attitudes of EFL teachers towards OI have a vital role for successful OI to take place. The present study provides rich information about Turkish EFL teachers' attitudes towards OI, the challenges they experience, and their perceptions about the strategies to integrate OI in EFL courses more successfully.

The findings revealed that Turkish EFL teachers do not have positive attitudes towards the implementation of OI for most of the aspects of OI. The most common reasons behind their negative attitudes can be listed as (1) teachers' inadequate knowledge and skills about educational technologies, (2) lack of students' motivation to participate in online sessions, (3) the shortcomings of virtual meeting applications, (4) lack of interaction in online sessions, and (5) some students' inadequate access to necessary equipment for successful online learning to take place. The findings also indicated that the EFL teachers, who had been taught about the educational technologies to be employed in OI, have more positive attitudes towards OI. 
It can be concluded that most of the EFL teachers in Turkey do not have adequate knowledge and necessary skills to conduct online lessons. Therefore, it is suggested that OI methodologies should be integrated into teacher training programs and current teachers should receive an in-service training on OI. Most of the challenges and the reasons behind teachers' negative attitudes towards OI can simply be overcome when they have the necessary knowledge and skills in this regard.

\section{Limitations and Suggestions for Further Research}

One limitation of this paper is that the number of participants in the two groups was not equal to each other. The number of participants who received training on the use of educational technologies for OI during their academic studies was less than the ones who didn't. Even though a significant difference was found between the attitudes of the two groups towards OI, the effect size was found to be low. If the number of participants had been equal in each group, the test could have provided more generalizable results, maybe with a higher effect size. Therefore, more studies should be conducted to investigate the impact of teacher training for OI methodologies on the attitudes of EFL teachers towards OI.

\section{Declarations}

Author contribution : MC and IT conceived the research ideas, worked on data collection, analysis, and draft writing; LU supervised the research throughout the process and revised the final draft.

Funding statement : The authors have not received any financial support from any agency or individual for the authorship and the publication of this paper.

Conflict of interest $\quad$ : The authors declare no conflict of interest.

Additional information: No additional information is available for this paper.

\section{REFERENCES}

Aliyyah, R. R., Rachmadtullah, R., Samsudin, A., Syaodih, E., Nurtanto, M., \& Tambunan, A. R. S. (2020). The perceptions of primary school teachers of online learning during the COVID-19 pandemic period: A case study in Indonesia. Journal of Ethnic and Cultural Studies, 7(2), 90-109. http://dx.doi.org/10.29333/ejecs/388

Allo, M. D. (2020). Is the online learning good in the midst of Covid-19 Pandemic? The case of EFL learners. Jurnal Sinestesia, 10(1), 1-10.

Almusharraf, N., \& Khahro, S. (2020). Students Satisfaction with Online Learning Experiences during the COVID-19 pandemic. International Journal of Emerging Technologies in Learning (iJET), 15(21), 246-267. https://doi.org/10.3991/ijet.v15i21.15647

Altay, İ. F., \& Altay, A. (2017). The impact of online reading tasks and reading strategies on EFL learners' reading test scores. Journal of Language and Linguistic Studies, 13(2), 136-152.

Atmojo, A. E. P., \& Nugroho, A. (2020). EFL classes must go online! Teaching activities and challenges during COVID-19 pandemic in Indonesia. Register Journal, 13(1), 49-76. https://doi.org/10.18326/rgt.v13i1.49-76

Belanger, F., \& Jordan, D. H. (2000). Evaluation and implementation of distance learning: Technologies, tools and techniques. Hershey, PA: Idea Publishing Group.

Carter, K., \& Doyle, W. (1995, June). Preconceptions in learning to teach. In The Educational Forum (Vol. 59, No. 2, pp. 186-195). Taylor \& Francis Group. https://doi.org/10.1080/00131729509336385

Çelik Korkmaz, Ş., \& Karatepe, Ç. (2018). The impact of multi-sensory language teaching on young english learners' achievement in reading skills. Novitas-ROYAL (Research on Youth and Language), 12(2), $80-95$.

Çelik Korkmaz, Ş., \& Karatepe, Ç. (2021). Multisensory language teaching: Its impact on the English vocabulary achievement of Turkish young learners. In Teaching Practices and Equitable Learning in Children's Language Education (pp. 151-170). IGI Global. http://dx.doi.org/10.4018/978-1-7998$\underline{6487-5}$

Cohen, L. , Manion, L. \& Morrison, K. (2007). Research Methods in Education (6 ${ }^{\text {th }}$ edition). London: Routledge. http://dx.doi.org/10.1111/j.1467-8527.2007.00388_4.x 
Dashtestani, R. (2014). English as a foreign language - teachers' perspectives on implementing online instruction in the Iranian EFL context. Research in Learning Technology, 22(1063519), 1-15. https://doi.org/10.3402/rlt.v22.20142

Erarslan, A., \& Topkaya, E. Z. (2017). EFL students attitudes towards e-learning and effect of an online course on students success in English. The Literacy Trek, 3(2), 80-101.

Eslami, Z. R., Mirzaei, A., \& Shadi, D. (2015). The role of asynchronous computer mediated communication in the instruction and development of EFL learners' pragmatic competence. System, 48, 99-111. https://doi.org/10.1016/j.system.2014.09.008

Hakim, B. (2020). Technology integrated online classrooms and the challenges faced by the EFL teachers in Saudi Arabia during the COVID-19 pandemic. International Journal of Applied Linguistics and English Literature, 9(5), 33-39. http://dx.doi.org/10.7575/aiac.ijalel.v.9n.5p.33

Hanson, W. E., Creswell, J. W., Clark, V. L. P., Petska, K. S., \& Creswell, J. D. (2005). Mixed methods research designs in counseling psychology. Journal of counseling psychology, 52(2), 224. http://dx.doi.org/10.1037/0022-0167.52.2.224

Hazaymeh, W. A. (2021). EFL students' perceptions of online distance learning for enhancing English language learning during Covid-19 pandemic. International Journal of Instruction, 14(3). https://doi.org/10.29333/iji.2021.14329a

Housseine, B., \& Rabha, S. (2020). The need of distance learning in the wake of COVID-19 in Morocco: Teachers' attitudes and challenges in the English foreign language instruction. International Journal of Language and Literary Studies, 2(3), 240-256. http://dx.doi.org/10.36892/ijlls.v2i3.326

Keegan, D. (2002). The future of learning: From e-learning to m-learning (ERIC Document Reproduction Service No. ED472435). Hagen, Germany: FernUniversitat Institute for Research into Distance Education.

Khatoony, S., \& Nezhadmehr, M. (2020). EFL teachers' challenges in integration of technology for online classrooms during Coronavirus (COVID-19) pandemic in Iran. AJELP: Asian Journal of English Language and Pedagogy, 8, 1-16. http://dx.doi.org/10.37134/ajelp.vol8.sp.1.2020

Lassoued, Z., Alhendawi, M., \& Bashitialshaaer, R. (2020). An exploratory study of the obstacles for achieving quality in distance learning during the covid-19 pandemic. Education Sciences, 10(9), 113. https://doi.org/10.3390/educsci10090232

Mathew, N. G., Sreehari, P., \& Al-Rubaat, A. M. (2019). Challenges and implications of virtual e-learning platform in EFL context: Perceptions of teachers. International Journal of English Language Teaching, 7(2), 100-116.

Nenakhova, E. (2021). Distance learning practices on the example of second language learning during coronavirus epidemic in Russia. International Journal of Instruction, 14(3), 807-826. https://doi.org/10.29333/iji.2021.14347a

Nugroho, A., Haghegh, M., \& Triana, Y. (2021). Emergency remote teaching amidst global pandemic: Voices of Indonesian EFL teachers. VELES Voices of English Language Education Society, 5(1), 66-80. https://doi.org/10.29408/veles\%20journal.v5i1.3258

Nugroho, A., \& Mutiaraningrum, I. (2020). EFL teachers' beliefs and practices about digital learning of English. EduLite: Journal of English Education, Literature and Culture, 5(2), 304. https://doi.org/10.30659/e.5.2.304-321

Octaberlina, L. R., \& Muslimin, A. I. (2020). EFL students perspective towards online learning barriers and alternatives using moodle/google classroom during covid-19 pandemic. International Journal of Higher Education, 9(6), 1-9. https://doi.org/10.5430/ijhe.v9n6p1

Osika, E., Johnson, R., \& Butea, R. (2009). Factors influencing faculty use of technology in online instruction: A case study. Online Journal of Distance Learning Administration, 12(1).

Pasaribu, T. A., \& Dewi, N. (2021). Indonesian EFL students' voices on online learning during COVID-19 through appraisal analysis. LEARN Journal: Language Education and Acquisition Research Network, 14(1), 399-426.

Rizvi, S., Rienties, B., \& Khoja, S. A. (2019). The role of demographics in online learning; A decision tree based approach. Computers \& Education, 137, 32-47. http://dx.doi.org/10.1016/j.compedu.2019.04.001

Sepulveda-Escobar, P., \& Morrison, A. (2020). Online teaching placement during the COVID-19 pandemic in Chile: challenges and opportunities. European Journal of Teacher Education, 43(4), 587-607. https://doi.org/10.1080/02619768.2020.1820981

Sun, S. Y. (2014). Learner perspectives on fully online language learning. Distance education, 35(1), 18-42. https://doi.org/10.1080/01587919.2014.891428

Tabachnick, B. G., and Fidell, L. S. (2013). Using multivariate statistics, 6th ed. Boston: Pearson.

Uzun, L. (2016). The educational and technical courses in the ELT program in Turkey: Do they contribute to ICT skills? Cogent Education, 3(1), 1141454. https://doi.org/10.1080/2331186X.2016.1141454 
Yen, Y. C., Hou, H. T., \& Chang, K. E. (2015). Applying role-playing strategy to enhance learners' writing and speaking skills in EFL courses using Facebook and Skype as learning tools: A case study in Taiwan. Computer Assisted Language $\quad$ Learning, 28(5), 383-406. https://doi.org/10.1080/09588221.2013.839568 